\title{
Biological nitrate removal processes from drinking water supply-a review
}

\author{
Anoushiravan Mohseni-Bandpi ${ }^{1}$, David Jack Elliott ${ }^{2}$ and Mohammad Ali Zazouli ${ }^{3^{*}}$
}

\begin{abstract}
This paper reviews both heterotrophic and autotrophic processes for the removal of nitrate from water supplies. The most commonly used carbon sources in heterotrophic denitrification are methanol, ethanol and acetic acid. Process performance for each feed stock is compared with particular reference nitrate and nitrite residual and to toxicity potential. Autotrophic nitrate removal has the advantages of not requiring an organic carbon source; however the slow growth rate of autotrophic bacteria and low nitrate removal rate have contributed to the fact that relatively few full scale plants are in operation at the present time.
\end{abstract}

Keywords: Acetic acid, Autotrophic, Denitrification, Ethanol, Heterotrophic, Nitrate removal

\section{Introduction}

Extensive research has focused on the removal of nitrate from groundwater and surface water due to its adverse health effects i.e. methemoglobinemia and possible formation of nitrosamines [1,2]. Today nitrate is a major water pollutant in many areas in the world such as Saudi Arabia [3], India [4], UK [5], North America [6], Australia [7], Morocco [8], Changshu in China [9] and Toyserkan in western Iran [10]. Nitrate pollution is caused by the intensive use of nitrogen fertilizers, crop irrigation with domestic wastewater and use of manure, therefore, it is concern of diffuse pollution [11].

Biological process has recently been applied in the field of drinking water treatment due to efficient performance and problems associated with other nitrate removing processes. Physical and chemical methods such as ion exchange, reverse osmosis, nanofiltration and electrodialysis, all show poor selectivity for nitrate removal $[12,13]$. As well as, the utility of these processes has been limited due to their expensive operation and subsequent disposal problem of the generated nitrate waste brine [11].These methods are more commonly used for the removal of inorganic substances other than

\footnotetext{
* Correspondence: zazoli49@yahoo.com

${ }^{3}$ Department of Environmental Health Engineering, Health Sciences Research Center and Faculty of Health, Mazandaran University of Medical Sciences, Sari, Iran

Full list of author information is available at the end of the article
}

nitrate [13]. The main disadvantage of the ion exchange process is that, it produces a nitrate, chloride and sulphate rich brine as a by-product which is difficult to dispose. Although new improved nitrate selection ion exchange resins are now available, this type of resin produces a residual waste stream, rich in nitrate [14-16].

Some processes such as membranes, adsorption, ion exchange resin and photocatalytic reduction are used for nitrate removal. However, these have some problems that include the need for waste brine disposal and posttreatment in membrane and ion exchange processes; saturated adsorbents in adsorption; low efficiency and high operation cost in photocatalytic processes [17-21]. In some cases biological denitrification may need to be coupled with an ion exchange resin process in order to optimize the overall efficiency of the nitrate removal [22]. In this process nitrate is removed by an ion exchange process. Regeneration of the rich nitrate load resin is carried out in a closed circuit by biological denitrification. A membrane bioreactor (MBR) was investigated for denitrification of nitrate $\left(\mathrm{NO}_{3}^{-}\right)$contaminated drinking water [23].

Biological denitrification has the advantage of harmless nitrogen gas being the major end product, and its use for nitrate removal has been promoted by the European Strategy as reference opposed to the physiochemical treatment alternatives [24-27].

The biological processes for denitrification can be of the fixed-film (attached growth) or suspended growth
C Biomed Central

(c) 2013 Mohseni-Bandpi et al.; licensee BioMed Central Ltd. This is an open access article distributed under the terms of the Creative Commons Attribution License (http://creativecommons.org/licenses/by/2.0), which permits unrestricted use,

distribution, and reproduction in any medium, provided the original work is properly cited. 
type. With fixed-film denitrification, the organisms are attached to an inert support media and although various media can be used, the goal is to maximize the surface area available for the biofilm to develop. These include fluidized bed reactors, packed bed reactors, and biofilters comprised of sand, anthracite, activated carbon, calcium carbonate, or sulfur [28].

The biological nitrate removal from drinking water supply first became operation in 1981, at the ChateauLandon in France [29]. Nowadays there are many full scale heterotrophic and autotrophic biological nitrate removal processes around the world [30-37]. An organic carbon source such as methanol, ethanol or acetic acid is required for cell growth and as the energy source for the heterotrophic bacteria. Most drinking water supplies lack sufficient quantities of organic carbon, required by the bacteria, to efficiently carry out the process of denitrification. Several inorganic compounds, such as sulphur and hydrogen, can also act as electron donors for autotrophic bacteria in place of an organic electron donor.

The type of electron donor is the main difference between heterotrophic and autotrophic biological nitrate removal processes. Removal of nitrate from water supplies, using methanol, ethanol and acetic acid is not well documented. This literature survey reviews the various aspects of denitrification of drinking water, using alternative types of bacteria and different reductants.

\section{Heterotrophic denitrification}

Heterotrophic bacteria can utilize different carbon compounds as electron donors. Commonly available carbon sources are sugar, glucose, acetone, acetic acid, ethanol and methanol [38-41]. A number of researchers developed natural materials (wheat straw, plant prunings etc.) as organic carbon sources for use in heterotrophic denitrification. The method was cost-effective but the pretreatment process was complicated and lengthy [25]. The denitrification rate is strongly affected by the type of carbon source [38-41]. Hamlin et al. showed that denitrification rate as g/day nitrate- $\mathrm{N}$ was $670,670,680$ and 670 for methanol, acetic acid, Starch (Glucose) and Molasses (Sucrose), respectively [38]. Also Xu et al. found that polycaprolactone and polylactic acid were suitable carbon sources for denitrification [40]. In generally, the rate is found to be very low, using sucrose and cellulose 0.07 and $0.008 \mathrm{~kg} / \mathrm{m}^{3} . \mathrm{d}$ respectively [42,43]. High rates can be obtained with acetic acid $[44,45]$. In practice carbon sources for nitrate removal from drinking water, are limited to simple and readily degradable substrates such as methanol, ethanol and acetic acid.

Methanol has been used as a carbon source for denitrification of drinking water reported by Rogalla et al. [32], Ayyasamy et al. [46] and Hall\&Zabel [47], whereas, extensive use of ethanol and acetic acid has been reported by Ghararah [48], Mohseni-Bandpi et al. [49], Magram [50], Green et al. [51] and Roennefhart [52]. Ghararah showed that ethanol as a carbon source was given better results as compared with methanol and acetic acid in an anoxic static bed column [48].

An inadequate dose of electron donor may result in a high level of nitrate and nitrite in the effluent whereas, over loading can cause carbonaceous contamination of the effluent which necessitates post-treatment. The effect of the under-dose of methanol has been reported in the UK and involves the production of intermediate nitrite which is more toxic than nitrate. This problem can be solved by re-oxidation of nitrite to nitrate via chlorination of the denitrified water, but this requires the provision of a high chlorine concentration [53].

The heterotrophic denitrification process is applied most extensively because of its high efficiency and the simplicity of the reactors required. However, effluent turbidity increasing due to bacterial growth and excessive organic carbon resulting in secondary pollution make it unfavorable [25].

\section{Methanol as a carbon source \\ Methanol requirement}

Methanol has been the most widely used exogenous carbon source for wastewater denitrification due to the lower cost and the lower bacterial cell yield compared to the other organic carbon sources [38,54-57]. Use of methanol as a carbon source in the process has been termed "safe only at low concentrations" but it is claimed to have potential toxic effects at higher concentrations [58]. The stoichiometric relationships describing this process are written as follows $[25,59,60]$.

Bacteria energy reactions step 1 and 2:

$$
\begin{aligned}
& 6 \mathrm{NO}_{3}^{-}+2 \mathrm{CH}_{3} \mathrm{OH} \rightarrow 3 \mathrm{NO}_{2}+2 \mathrm{CO}_{2}+4 \mathrm{H}_{2} \mathrm{O} \\
& 6 \mathrm{NO}_{2}^{-}+5 \mathrm{CH}_{3} \mathrm{OH} \rightarrow 3 \mathrm{~N}_{2}+3 \mathrm{CO}_{2}+3 \mathrm{H}_{2} \mathrm{O}+6 \mathrm{OH}^{-}
\end{aligned}
$$

Overall respiratory reaction:

$$
6 \mathrm{NO}_{3}^{-}+5 \mathrm{CH}_{3} \mathrm{OH} \rightarrow 3 \mathrm{~N}_{2}+5 \mathrm{CO}_{2}+7 \mathrm{H}_{2} \mathrm{O}+6 \mathrm{OH}^{-}
$$

In addition to the dissimulation reaction mentioned above, nitrate is also used in cell anabolism forming a compound of the form $\mathrm{C}_{5} \mathrm{H}_{7} \mathrm{O}_{2} \mathrm{~N}$. Approximately 40 percent of the methanol and 10 percent of the nitrate are consumed for cell anabolism [61]. However, the actual amount of methanol required in the influent is higher than that obtained from theoretical calculations. 
It has been suggested that the optimum $\mathrm{M} / \mathrm{N}$ ratio required for efficient denitrification obeys the following equation [60].

$$
\mathrm{C}_{\mathrm{m}}=2.47\left(\mathrm{NO}_{3}-\mathrm{N}\right)+1.53\left(\mathrm{NO}_{2}-\mathrm{N}\right)+0.87(\mathrm{DO})
$$

Where: $C_{m}=m g / l$ methanol required for denitrification, $\mathrm{NO}_{3}-\mathrm{N}=$ Initial nitrate-nitrogen concentration $\mathrm{mg} / \mathrm{l}$, $\mathrm{NO}_{2}-\mathrm{N}$ = Initial nitrite-nitrogen concentration $\mathrm{mg} / \mathrm{l}$, $\mathrm{DO}=$ Initial dissolved oxygen concentration $\mathrm{mg} / \mathrm{l}$.

Jeris et al. claimed that the actual amount of Methanol required for an efficient denitrification, is $20-25$ percent higher than that suggested by other researchers $[59,60,62]$.

$$
\begin{aligned}
\mathrm{NO}_{3}^{-} & +1.08 \mathrm{CH}_{3} \mathrm{OH}+\mathrm{H} \rightarrow 0.065 \mathrm{C}_{5} \mathrm{H}_{7} \mathrm{O}_{2} \mathrm{~N}+0.46 \mathrm{~N}_{2} \\
& +0.76 \mathrm{CO}_{2}+2.44 \mathrm{H}_{2} \mathrm{O}
\end{aligned}
$$

\section{Health effect}

The main disadvantage of using Methanol, is the potential toxicity of the residual Methanol in the denitrified effluent water $[63,64]$. Methanol can cause blindness at a concentration of $100 \mathrm{mg}$ per $\mathrm{kg}$ of body mass. It can be lethal at a minimum dose of $340 \mathrm{mg} / \mathrm{Kg}$. It has been argued [58] that, formaldehyde is a toxic by product during the oxidation of methanol. Adriaan, concluded that, methanol was a poor substrate for the denitrification process, and suggested that, ethanol and acetic acid were more suitable as carbon sources for the process [58]. The Uk Department of the Environmental specifies a maximum admissible methanol concentration (MAC) of $0.25 \mathrm{mg} / \mathrm{l}$ for distributed water [53].

In contrast to the above conclusions Cara et al. argued that the actual quantities of methanol $\mathrm{mg} / \mathrm{kg}$ ) in denitrified water, would be 4 to 5 orders of magnitude less than the toxic concentration [63]; It has been reported that, no direct evidence exists for cytotoxic [65], toxicological and mutagenic [66] activity at low methanol concentration.

Liessens et al. [61] calculated that drinking water denitrified using methanol would contribute approximately 10 percent to the total average direct intake from all sources. This indicates that, the health risks from methanol in water are negligible when the concentration is within the prescribed limit. So far, there has not been a comprehensive study on the probable long term effects on the human body of methanol intake in low concentrations in the daily diet [61].

It may be noted that biological denitrification using methanol as a carbon source results in the complete dehydrogenation of the organic substrate [25]. Thus no intermediate compound will be accumulated during the process. However, the UKDOE recommended continuous on-line monitoring of the methanol concentration in the denitrified water [53].

Elimination of methanol from the effluent of the denitrification process can be readily achieved. The result of the investigations carried out by Mohseni and Elliott indicate that methanol remaining in the effluent of the denitrification process can easily be oxidised by the biological action of aerobic bacteria [67-69].

\section{Denitrification with methanol as a carbon source}

Chang et al. investigated the performance of an anoxic filter with one inch gravel filter media for nitrate removal from water using methanol as a carbon source. They reported more than 90 percent removal of approximately $20 \mathrm{mg} / \mathrm{l}$ influent nitrate at a temperature $12^{\circ} \mathrm{C}$. It was however, noted that the denitrified water would need some post treatment [70].

In an investigation by Croll, et al., methanol, ethanol and acetic acid were used as carbon sources. In this study methanol was applied over long periods, while ethanol and acetic acid were used for short periods. Up to $45 \mathrm{mg} / \mathrm{l}$ methanol was required to remove nitrate from water having $12 \mathrm{mg} / \mathrm{l}$ dissolved oxygen and $13 \mathrm{mg} / \mathrm{l}$ nitrate-nitrogen. The denitrified water was reaerated over a cascade aerator and was kept for a retention time of 1 hour to remove residual methanol before final consumption. No operational problems were observed during the treatment and nitrite concentration in the effluent was controlled by adjusting the dose of the carbon source. It was concluded that the cost of using the ethanol and acetic acid for - nitratenitrogen removal would be respectively 25 and 50 higher than for methanol [71]. The use of a fluidised bed with methanol as a carbon source showed that the highest denitrification rate was found to be $205 \mathrm{~g}$ $\left(\mathrm{NO}_{2}+\mathrm{NO}_{3}-\mathrm{N}\right) / \mathrm{m}^{3}$.hr, with an average nitrate-nitrogen removal of efficiency 97.3 percent [72,73].

The use of an upward flow, fluidized sand bed using a spring fed stream was investigated by the Water Research Centre in conjunction with Anglian Water at Bucklesham. Methanol was used as an organic carbon source and phosphate was added to satisfy nutrient requirements. The plant was found to be efficient for nitrate removal. Intermittent high nitrite concentrations were however, observed during a one year experimental period. This investigation was followed by Hall et al. under support from the Water Research Centre for two years [47]. According to Hiscock et al. [74] the plant achieved a removal of $14 \mathrm{mg} / \mathrm{l}$ nitrate-nitrogen at a temperature of $2^{\circ} \mathrm{C}$. Methanol was used as an organic carbon source with a dose of $45 \mathrm{mg} / \mathrm{l}$. To avoid excess carbon entering the end product, the plant operated under a carbon limited condition with a residual 3$5 \mathrm{mg} / \mathrm{l}$ remaining in the treated water. The carbon limited operation however, produced occasional nitrite 
concentrations of more than $2 \mathrm{mg} / \mathrm{l}$ in the product water. Consequently, excess chlorine was required for nitrite removal $[74,75]$.

Pilot plant studies, carried out at Tucking Mill by Wessex Water using a $10 \mathrm{~m}^{3} / \mathrm{h}$ fluidized bed for the denitrification of river water, containing $88 \mathrm{mg} / 1 \mathrm{NO}_{3}$, have been described by the UKDOE [53]. In this study methanol was used as a carbon source, with a dose of $30 \mathrm{mg} / \mathrm{l}$. The TOC and suspended solids of the water increased as a result of the denitrification process. Nitrite production also occurred during winter operation. Additional chlorination was required to eliminate the residual organic carbon and nitrite in the product water.

Use of a semi industrial biological fluidized bed system has been investigated by Liessens et al. [61] with a capacity of $40 \mathrm{~m}^{3} / \mathrm{h}$ and methanol as a carbon source at De Blankaart in Belgium for removing nitrate from surface water. The plant achieved a nitrate removal of $9 \mathrm{Kg} \mathrm{N03} / \mathrm{m}^{3}$. $d$ at $3.5^{\circ} \mathrm{C}$. Residual methanol was readily removed by the existing downstream drinking water treatment processes. It was concluded that the heterotrophic denitrification in a fluidized bed reactor using methanol as a substrate was appropriate for surface water at low temperature. Long term stable operation was demonstrated as well as the ability to achieve high volumetric loading at short residence times. The authors noted that whenever conventional water treatment is used downstream, no residual carbon source can reach the distribution system and give rise to bacterial after growth [61].

\section{Ethanol as a carbon source Ethanol requirement}

The two main mechanisms for ethanol oxidation are as follows [76]:

a) Bacterial respiration

$$
2 \mathrm{NO}_{3}^{-}+5 \mathrm{C}_{2} \mathrm{H}_{5} \mathrm{OH} \rightarrow 6 \mathrm{~N}_{2}+10 \mathrm{CO}_{2}+9 \mathrm{H}_{2} \mathrm{O}+12 \mathrm{OH}-
$$

A dose of $0.31 \mathrm{mg}$ of ethanol is required to remove $1 \mathrm{mg}$ of $\mathrm{NO}_{3}$ by bacteria respiration.

b) Bacterial synthesis:

$$
\begin{aligned}
& 97 \mathrm{NO}_{3}^{-}+5 \mathrm{C}_{2} \mathrm{H}_{5} \mathrm{OH} \rightarrow 5 \mathrm{C}_{7} \mathrm{H}_{5} \mathrm{O}_{2} \mathrm{~N}+75 \mathrm{CO}_{2} \\
& \quad+84 \mathrm{H}_{2} \mathrm{O}+46 \mathrm{~N}_{2}+97 \mathrm{OH}-
\end{aligned}
$$

A dose of $0.38 \mathrm{mg}$ of ethanol is required to remove $1 \mathrm{mg}$ of $\mathrm{NO}_{3}$.

The theoretical amount of ethanol needed as a substrate i.e. the stoichiometrical amount is $2 \mathrm{~g} \mathrm{C}_{2} \mathrm{H}_{5} \mathrm{OH}$ per $\mathrm{g}$ nitrate-nitrogen. In practice, however, approximately $3 \mathrm{~g} \mathrm{C}_{2} \mathrm{H}_{5} \mathrm{OH}$ per $\mathrm{g}$ nitrate-nitrogen is required (0.6-0.7 $\mathrm{g} \mathrm{C}_{2} \mathrm{H}_{\mathrm{s}} \mathrm{OH}$ per $\mathrm{g} \mathrm{N}_{3}$ ). Approximately $0.4-0.6 \mathrm{Kg}$ $\mathrm{SS}$ of excess biomass is produced per $\mathrm{Kg} \mathrm{N}$ [52].
The following equations may also be used for calculating the substrate requirement [32].

$$
\mathrm{C}=\left(\mathrm{N}-\mathrm{NO}_{3}\right) \times 0.475+\left(\mathrm{O}_{2}\right) 0.55
$$

Where, $\left(\mathrm{N}-\mathrm{NO}_{3}\right)=$ Nitrate removal rate $\mathrm{mg} / \mathrm{l}$,

$\mathrm{O}_{2}=$ Dissolved oxygen in raw water $\mathrm{mg} / \mathrm{l}$,

$\mathrm{C}=$ Ethanol concentration $\mathrm{mg} / \mathrm{l}$.

In an investigation by Green et al. [51], the optimum ethanol to nitrate-nitrogen ratio was found to be 2.2. other research showed that the ratio for efficient nitratenitrogen removal with minimum combined effluent nitrite and ethanol to be $2.3[51,77]$.

\section{Health effect}

To overcome the possible toxicity problem due to use of methanol as a electron donor in the nitrate removal process, ethanol has been recommended as alternate safe organic carbon source. No limit has been set for ethanol in potable water. Several states have set guidelines or standards for ethanol in ambient air but USEPA has suggested a permissible ambient goal of $26 \mathrm{mg} / \mathrm{l}$ based on health effects [78].

\section{Denitrification with ethanol as a carbon source}

Ethanol also was applied in an investigation by Croll et al. using a fluidized bed reactor in short periods at doses of $33 \mathrm{mg} / \mathrm{l}$ for removing approximately $12 \mathrm{mg} / \mathrm{l}$ DO and $13 \mathrm{mg} / \mathrm{NO}_{3}-\mathrm{N}$. The ethanol requirement was $0.5 \mathrm{mg}$ ethanol/mg DO and $2 \mathrm{mg}$ ethanol $/ \mathrm{mg}$ NO3-N [71]. Mekonen et al. was investigated the efficiency of a sequencing batch reactor in denitrification of drinking water with relatively high nitrate concentrations with Ethanol as a carbon source. It was found that ethanol at a $\mathrm{COD} / \mathrm{N}$ of 2 was sufficient to reduce nitrate concentrations to acceptable levels $(<10 \mathrm{mg} / \mathrm{L}$ as $\mathrm{N})$. They claimed that a sequencing batch reactor has the potential of being used as an alternative configuration for biological denitrification of drinking water [79].

The use of heterotrophic microorganisms has been described by Roennefhart [52] for removing nitrate from water supplies in the "DENIPOR" process in Germany. Methanol and acetic acid were used as carbon sources initially, followed by ethanol. The bacteriological study showed that the bacteria found in the denitrified water were similar to those in other drinking waters, and consisted mainly of Pseudomonas with dominant species being Pseudomonas fluroscence and Pseudomonas putida. The plant achieved a removal efficiency of 90 to $95 \%$ at loading rates of 2.5 to $5.3 \mathrm{~kg} / \mathrm{m}^{3} / \mathrm{d}$. N. Based on good results of pilot scale studies, the first full scale treatment plant is being built of the water works of the towns of Langenfeld and Monheim (Germany) [52]. 
Rogalla [32] used a pilot-scale packed bed reactor with a mineral medium and ethanol as the carbon source to remove nitrate from groundwater. The results obtained from the pilot scale studies were applied to full scale reactors. Full scale studies at flow rates of $80 \mathrm{~m}^{3} / \mathrm{hr}$ and $1400 \mathrm{~m}^{3} / \mathrm{hr}$ showed that the complete removal of nitrogen and organic compounds were achieved. Denitrified water was passing through a two-layer media. The first layer consisted of aerated activated carbon for the removal of excess carbonaceous pollution, and to increase the available dissolved oxygen, while the second layer was made of fine sand to remove suspended solids [32].

Two full scale biological nitrate removal processes called "Nitrazur" and "Biodent" with capacities 35-70 and $80 \mathrm{~m}^{3} / \mathrm{h}$ respectively have been operated in France. Acetic acid was used as a carbon source for a short period, which then was followed by the use of ethanol [36]. The first plant achieved a nitrate removal efficiency of $72 \%$ with an ethanol dose of $3.1 \mathrm{~g}$ per $\mathrm{g}$ of nitrate-N removed. The average consumption of ethanol varied from 0.65 to $0.75 \mathrm{~g}$ per $\mathrm{g}$ of nitrate removed. Based on good performance of the "Bioden" reactor, a similar large scale facility in Dennemout near Paris with a capacity $400 \mathrm{~m}^{3} / \mathrm{h}$ was investigated for removal of nitrate and ammonia, using fixed heterotrophic bacteria and ethanol as the electron donor. The influent nitrate and ammonia concentrations were $40-65$ and $2-3.5 \mathrm{mg} / \mathrm{l}$ respectively. The corresponding effluent nitrate and ammonia concentration were $15-17$ and $0.01-0.02 \mathrm{mg} / \mathrm{l}$ respectively. The denitrified water was applied to an aerated two-layer sand and activated carbon filter, before ozonation to oxidise residual ethanol and micro pollutants. No residual ethanol and nitrite were observed in the final effluent.

Continuous rotating biological contactors were investigated in Germany for nitrate elimination from potable water using ethanol as a substrate. The plant consisted of two RBC units in series. The first unit operated under anoxic conditions where denitrification occurred, while the second reactor operated under aerobic conditions. Ethanol and nutrients were dosed automatically, regulated by the nitrate concentration of the raw water. No change in chemical composition of the water was observed, except a reduction in the nitrate concentration. The major operational advantage of the combination was found to be continuous elimination of nitrate and the removal of excess ethanol. Problems of nitrite production were only experienced during the initial period of the experiments. To ensure the removal of excess biomass and organic matter, the final product from the denitrification reactor was passed through the filter beds and the disinfection stage of the water treatment works. It was concluded that, the system was capable of being integrated into the standard water treatment process sequence, rather than replacing the existing physiochemical treatment processes [33].
A pilot plant tube reactor, with a capacity of $650 \mathrm{~m}^{3} / d$ was operated using ethanol as a carbon source in Germany [33]. Considering the high performance of the reactor for removal of nitrate, two full scale reactors each with a capacity of $6100 \mathrm{~m}^{3} / d$ were made operational in 1992. Denitrified water was subjected to post treatment consisting of aeration, multi-layer activated carbon, $\mathrm{pH}$ adjustment, and disinfection with chlorine. In November 1992 the water was fed into the distribution system for drinking purposes. The analysis of water quality showed that, the final effluent conformed to EC drinking water standards.

\section{Acetic acid as a carbon source}

Acetic acid is more readily metabolisabled than methanol and glucose. It has demonstrated advantages over methanol; higher denitrification rate, high buffering capacity and absence of toxic effects and therefore may be suitable to replace the role of methanol in the denitrification process [80-82].

\section{Acetic acid requirement}

The stoichiometry of acetic acid as a carbon source for the denitrification process was found experimentally to conform to the following equations $[36,80]$ :

$$
\begin{aligned}
& 0.84 \mathrm{CH}_{3} \mathrm{COOH}+\mathrm{NO}_{3}^{-} \rightarrow 0.08 \mathrm{C}_{5} \mathrm{H}_{7} \mathrm{O}_{2} \mathrm{~N} \\
& +\mathrm{HCO}_{3-}+0.3 \mathrm{CO}_{2}+0.92 \mathrm{H}_{2} \mathrm{O}+0.46 \mathrm{~N}_{2}
\end{aligned}
$$

From the equation above approximately $4.1 \mathrm{~g}$ acetic acid is required to remove of $1 \mathrm{~g}$ N03-N. Dahab [80] discovered that the mean acetic acid (as carbon) to nitrogen removal ratio ( $C / N$ removal ratio) was 1.5 [80].

The average acetic acid consumption in an investigation by Richard et al. [36], varied from 0.9 to $1.6 \mathrm{~g}$ per $\mathrm{g}$ of nitrate removed [36]. The acetic acid requirement in an investigation by Croll et al., was $1.2 \mathrm{mg} / \mathrm{mg} \mathrm{DO}$ and $3.5 \mathrm{mg}$ acetic acid/mg $\mathrm{NO}_{3}-\mathrm{N}$ [71]. The acetic acid to nitratenitrogen $(A / N)$ ratio in an investigation by Mohseni and Elliott. was found to be in the range of 4.2 to $4.3[49,68]$. Table 1 presented some of the organic carbon to nitrate-nitrogen ratios reported in the literature.

\section{Denitrification using acetic acid as a carbon source}

Acetic acid as a carbon source was investigated in nitrate removal from drinking water using a packed bed reactor. The process achieved nearly 100 percent nitrate removal efficiency with an influent nitrate-nitrogen concentration of $100 \mathrm{mg} / \mathrm{l}$ [80]. Acetic acid was applied in an investigation by Croll et al. (1985) using a fluidised bed reactor in short periods at doses of $57 \mathrm{mg} / \mathrm{l}$ for removing approximately $12 \mathrm{mg} / \mathrm{l} \mathrm{DO}$ and $13 \mathrm{mg} / \mathrm{l} \mathrm{NO}_{3}-\mathrm{N}$ [71].

A fixed film reactor followed by aquifer recharge for heterotrophic denitrification of groundwater, was investigated in Germany by the DVGW research department 
Table 1 Carbon to nitrate-nitrogen ratios for different carbon sources

\begin{tabular}{|c|c|c|c|}
\hline Carbon source & Carbon to nitrate-nitrogen ratios & Type of system & References \\
\hline Methanol & $2.9 \mathrm{mgM}^{\mathrm{a}} / \mathrm{mg} \mathrm{NO}_{3}-\mathrm{N}$ & Rotating biological contactor & {$[69]$} \\
\hline Methanol & $2 \mathrm{mgM}^{\mathrm{a}} / \mathrm{mg} \mathrm{NO}_{3}-\mathrm{N}$ & Intensified biofilm-electrode reactor (IBER) & [25] \\
\hline Methanol & $2.6 \mathrm{mgM} / \mathrm{mg} \mathrm{NO}_{3}-\mathrm{N}$ & Fluidized bed reactor & [71] \\
\hline Methanol & $2.6 \mathrm{mgM} / \mathrm{mg} \mathrm{NO}_{3}-\mathrm{N}$ & Rotating biological contactor & [27] \\
\hline Methanol & $3.1 \mathrm{mgM} / \mathrm{mg} \mathrm{NO}_{3}-\mathrm{N}$ & Fluidized bed reactor & [72] \\
\hline Methanol & $3.2 \mathrm{mgM} / \mathrm{mg} \mathrm{NO}_{3}-\mathrm{N}$ & Fluidized bed reactor & [61] \\
\hline Ethanol & $2.35 \mathrm{mgE}^{\mathrm{b}} / \mathrm{mg} \mathrm{NO}_{3}-\mathrm{N}$ & Rotating biological contactor & [69] \\
\hline Ethanol & $2 \mathrm{mgE} / \mathrm{mg} \mathrm{NO}_{3}-\mathrm{N}$ & Fluidized bed reactor & [71] \\
\hline Ethanol & $2.2 \mathrm{mgE} / \mathrm{mg} \mathrm{NO}_{3}-\mathrm{N}$ & Packed bed reactor & [32] \\
\hline Ethanol & $3 \mathrm{mgE} / \mathrm{mg} \mathrm{NO}_{3}-\mathrm{N}$ & Fixed film bed reactor & [52] \\
\hline Ethanol & 2.8-3.3 mgE/mg NO $3-\mathrm{N}$ & Fluidized bed reactor & [36] \\
\hline Acetic acid & $4.3 \mathrm{mgA}^{\mathrm{C}} / \mathrm{mg} \mathrm{NO}_{3}-\mathrm{N}$ & Rotating biological contactor & [69] \\
\hline Acetic acid & $3.5 \mathrm{mgA} / \mathrm{mg} \mathrm{NO}_{3}-\mathrm{N}$ & Fluidized bed reactor & [71] \\
\hline Acetic acid & $3.9 \mathrm{mgA} / \mathrm{mg} \mathrm{NO}_{3}-\mathrm{N}$ & Packed bed reactor & {$[80]$} \\
\hline Acetic acid & $4.1 \mathrm{mgA} / \mathrm{mg} \mathrm{NO}_{3}-\mathrm{N}$ & Packed bed filter & [83] \\
\hline Acetic acid & $4 \mathrm{mgA} / \mathrm{mg} \mathrm{NO}_{3}-\mathrm{N}$ & Packed bed reactor & {$[36]$} \\
\hline
\end{tabular}

${ }^{\mathrm{a}}$ Methanol; ${ }^{\mathrm{b}}$ Ethanol; ${ }^{\mathrm{c}}$ Acetic acid.

[83]. The total process consists of two steps; an above ground technical treatment followed by underground naturally occurring treatment. The denitrifying bacteria were attached to a granular medium in the reactor through which the water is passed with a downward flow. Acetic acid was added as a substrate to provide energy for the microorganisms together with a small amount of phosphate. At influent nitrate concentrations of 55 to $100 \mathrm{mg} / \mathrm{l}$, the nitrate removal rate was found to be 2.5 to $3.5 \mathrm{~kg} / \mathrm{m}^{3}$.d respectively, having residual acetic acid in the effluent of $1 \mathrm{mg} / \mathrm{l}$. The removal rate however decreased significantly when the reactor was operated under limited acetic acid i.e. $0.1 \mathrm{mg} / \mathrm{l}$ instead of $1 \mathrm{mg} / \mathrm{l}$. After 18 months of pilot scale operation and good results obtained with the system, a full scale plant is was erected at Neuss to treat $30-55$ percent of the total flow of $800 \mathrm{~m}^{3} / \mathrm{h}$. The denitrified water was then mixed with the mainstream. Nitrate levels were reduced from the initial level of $55-60 \mathrm{mg} / \mathrm{l}$ to $25 \mathrm{mg} / \mathrm{l}\left(\mathrm{as} \mathrm{NO}_{3}\right)$ [82].

\section{Autotrophic denitrification}

Autotrophic denitrification is gaining growing attention because it does not require an organic carbon as an electron donor. Autotrophic denitrifiers utilize inorganic carbon compounds (e.g., $\mathrm{CO}_{2}, \mathrm{H}_{2} \mathrm{CO}_{3}, \mathrm{HCO}_{3}^{-}$) as their carbon source. The substrates required for autotrophic denitrifying microorganisms are hydrogen gas and sulphide ion. Energy is derived from the oxidation reactions of inorganic elements such as hydrogen or various sulfur compounds $\left(\mathrm{H}_{2} \mathrm{~S}, \mathrm{~S}, \mathrm{~S}_{2} \mathrm{O}_{3}\right)$. In this process hydrogen ions are produced, indicating that alkalinity is consumed by the reaction. Therefore alkaline, like limestone, is usually added in the sulfur based autotrophic denitrification reactors [24]. The autotrophic micro-organisms in the nitrate removal process are very few in species and characterized by slow growth resulting in low solids production and low efficiency.

\section{Hydrogen gas as a reductant}

The use of hydrogen oxidising micro-organisms for biological denitrification have been described by some reseachers [76,84-86]. It was shown that autotrophic microorganisms such as Parcoccus could use molecular hydrogen as a substrate and inorganic carbon such as $\mathrm{CO}_{2}$ and $\mathrm{HCO}_{3}$ for energy requirements. Nitrate can be removed in the absence of oxygen by acting as an electron acceptor and is reduced to harmless nitrogen gas.

\section{Hydrogen requirement}

The consumption of hydrogen gas for the denitrification reaction may be described as follows [82]:

$$
\begin{aligned}
& 2 \mathrm{NO}_{3}^{-}+2 \mathrm{H}_{2} \rightarrow 2 \mathrm{NO}_{2}^{-}+2 \mathrm{H}_{2} \mathrm{O} \\
& 2 \mathrm{NO}_{2}^{-}+3 \mathrm{H}_{2} \rightarrow \mathrm{N}_{2}+2 \mathrm{H}_{2} \mathrm{O}+2 \mathrm{OH}^{-}
\end{aligned}
$$

Overall

$$
2 \mathrm{NO}_{3}^{-}+5 \mathrm{H}_{2} \rightarrow \mathrm{N}_{2}+4 \mathrm{H}_{2} \mathrm{O}+2 \mathrm{OH}^{-}
$$

$0.35 \mathrm{mg} \mathrm{H}_{2}$ is required to complete the reduction of $1 \mathrm{mg}$ nitrate nitrogen. Also one mole of $\mathrm{OH}^{-}$is released per mole of nitrate nitrogen reduced [87]. 


\section{Denitrification using hydrogen}

A full scale autotrophic groundwater denitrification plant, comprising four fixed film up flow nitrate removal reactors containing hydrogen as a substrate was operated at Monchengladbach [30]. The plant was successful in completely removing nitrate-nitrogen. The denitrified water was passed through a double-layer filter to remove solids. The influent nitrate was found to reduce from 80 to $25 \mathrm{mg} / \mathrm{l} \mathrm{N0} \mathrm{N}_{3}$. The denitrified water was then blended with $100 \mathrm{~m}^{3} / \mathrm{hr}$ of mainstream and pumped to the distribution system for drinking purposes. Gormen et al. that a hydrogenotrophic denitrification reactor was designed for the removal of nitrate from aquaria, showed that during batch experiments removal rates up to $36 \mathrm{mg} \mathrm{N} / \mathrm{l}$ reactor per day whereas, during a 7 day aquarium test, a nitrate removal rate up to $18.5 \mathrm{mg} \mathrm{N} / \mathrm{l}$ reactor per day [88]. A large scale pilot plant using autotrophic bacteria with hydrogen as a substrate showed that the plant achieved more than 97\% nitrate- nitrogen removal efficiency with influent nitrate concentration of $18 \mathrm{mg} / \mathrm{l}$. The hydrogen consumption was $0.48 \mathrm{mg}$ per $\mathrm{mg}$ of nitrate-nitrogen removed. The denitrified water after aeration was passing through 2-layer filtration and disinfected by UV light to remove solids and microorganisms. The final effluent was good of bacteriological and chemical quality [89].

\section{Sulphur and sulphide ions as a reductant Sulphur requirement}

In addition to hydrogen gas, sulphur and its derivates can also be used as an electron donor for autotrophic bacteria [31,90-95]. Autotrophic bacteria such as Thiobacillus denitrificans $[26,96]$ and Thiomicrospira denitrificans [97] have been used sulphur as a substrate for removing nitrate from water supplies according to the following reaction:

$$
5 \mathrm{~S}+6 \mathrm{NO}_{3}^{-}+2 \mathrm{H} 2 \mathrm{O} \rightarrow 3 \mathrm{~N}_{2}+5 \mathrm{SO}_{4}^{2-}+4 \mathrm{H}^{+}
$$

In addition to inorganic nitrogen gas the by-products; sulphate, hydrogen ions and biomass, are also formed [98]. Batchelor and Lawrence have conducted kinetic studies with elemental sulfur. The stoichiometric equation for the reduction of nitrate using elemental sulfur proceeds as follows [90]:

$$
\begin{aligned}
55 \mathrm{~S} & +50 \mathrm{NO}_{3}^{-}+38 \mathrm{H}_{2} \mathrm{O}+20 \mathrm{CO}_{2}+4 \mathrm{NH}_{4}^{+} \\
& \rightarrow 4 \mathrm{C}_{5} \mathrm{H}_{7} \mathrm{~N}_{2} \mathrm{O}+25 \mathrm{~N}_{2}+55 \mathrm{SO}_{4}^{2-}+64 \mathrm{H}^{+}
\end{aligned}
$$

\section{Denitrification using sulphur}

Sulfur-based autotrophic denitrification has been studied in the treatment of drinking water [93,99]. The use of sulphur/limestone as a substrate has been investigated at pilot scale in the Netherlands for removing nitrate from groundwater $[100,101]$. The system was designed with an up flow filtration rate of $0.25-0.5 \mathrm{~m} / \mathrm{h}$. The effluent nitrate varied from 1-2 mg/l. On the basis of pilot scale results, a full scale facility with a capacity of $35 \mathrm{~m}^{3} / \mathrm{h}$ was constructed. The plant comprised a vacuum deaerator for removal of nitrogen and oxygen, a slow sulphur/ limestone filter for the denitrification process, a cascade for aerating the water and an infiltration pond for collecting the denitrified water. It was noted that the combination of vacuum deaeration and sulphur/limestone filter could offer a simple process for nitrate removal from groundwater. Based on good performance a $100 \mathrm{~m}^{3} / \mathrm{hr}$ full scale plant was constructed [91]. Darbi et al. [100] conducted a study of nitrate removal by using sulphur and limestone autotrophic denitrification, by Thiobacillus denitrificans. The influent $\mathrm{NO}_{3}-\mathrm{N}$ concentration was 94,57 and $10 \mathrm{mg} / \mathrm{l}$ with a maximum hydraulic retention time of $33 \mathrm{~d}$. It was observed that nitrate removal efficiency was $>95 \%$ at Sulphur: Limestone ratio of 3:1 [102]. Similar study that the influent $\mathrm{NO}_{3}-\mathrm{N}$ concentration was $30 \mathrm{mg} / \mathrm{l}$ with a hydraulic retention time of $30 \mathrm{~d}$ showed that nitrate removal efficiency was 95 to $100 \%$ with alkalinity control and 80 to $85 \%$ without alkalinity control [103].

The autotrophic denitrification process in a lab scale up flow bio filter by using sulfur-limestone indicated that nitrate removal rate was about $90 \%$ at the hydraulic retention time (HRT) of $3 \mathrm{hr}$ and temperature of $20-25^{\circ} \mathrm{C}$. it was showed that autotrophic denitrification process with sulfur-limestone as the electron donor was feasible to remove the nitrate and nitrite, especially from the low concentration water such as eutrophicated surface water, underground water, or wastewater treatment plant effluent [24].

The results of the full scale plant conform to the pilot scale plant. Nitrate removal in autotrophic denitrification is accompanied by the production of hydrogen ions thus lowering the $\mathrm{pH}$ level. $\mathrm{pH}$ adjustment is therefore necessary to maintain the optimum $\mathrm{pH}$ range for bacterial activity between 6.4 to 6.8 . Consequently, limestone granules are added to sulphur to maintain the $\mathrm{pH}$ value during the denitrification process [101]. A summary of full scale and pilot scale heterotrophic and autotrophic nitrate removal processes are shown in Table 2.

\section{Conclusions}

The following main conclusions may be drawn from this literature survey.

i. The use of biological denitrification for removal of nitrate from drinking water is well established. Nowadays there are many full scale biological nitrate removal process, hetrotrophic as well as autotrophic in European countries. 
Table 2 Lists of some pilot and full scale heterotrophic and autotrophic denitrification from drinking water

\begin{tabular}{|c|c|c|c|c|c|c|c|}
\hline & Process $^{a}$ & Electron donor & $\begin{array}{c}\text { Capacity } \\
\left(\mathrm{m}^{3} / \mathrm{hr}\right)\end{array}$ & Influent $\mathrm{NO}^{3}-\mathrm{N}(\mathrm{mg} / \mathrm{l})$ & $\mathrm{NR}^{\mathrm{b}}(\mathrm{Kg} / \mathrm{m} 3)$ & Efficiency (\%) & References \\
\hline \multirow[t]{15}{*}{ Heterotrophic" } & RBC(pilot Scale) & Methanol & 0.15 & 40 & 0.1 & 93 & [69] \\
\hline & IBER(Pilot Scale) & Methanol & - & 50 & - & 97 & {$[25]$} \\
\hline & MBR(Pilot Scale) & Methanol & - & 200 & - & 99 & {$[23]$} \\
\hline & FBR(Full Scale) & Methanol & 40 & $60-80$ & 0.18 & 96 & {$[61]$} \\
\hline & RBC(Pilot Scale) & Methanol & - & $15-20$ & - & $91-93$ & {$[27]$} \\
\hline & RBC(pilot Scale) & Ethanol & 0.15 & 40 & 0.9 & 91 & [69] \\
\hline & "Nitrazur "(Full Scale) & Ethanol & 35 & 16.3 & - & 72 & [36] \\
\hline & "Biodenit"(Full Scale) & Ethanol & 400 & 14.7 & 0.41 & 74 & [32] \\
\hline & $\begin{array}{l}\text { Batch-bio-film carrier } \\
\text { (pilot scale) }\end{array}$ & $\begin{array}{c}\text { liquorice } \\
\text { (Glycyrrhiza glabra) }\end{array}$ & - & - & - & 87 & [104] \\
\hline & $\begin{array}{l}\text { Batch-bio-film carrier } \\
\text { (pilot scale) }\end{array}$ & $\begin{array}{c}\text { Giant reed } \\
\text { (Arundo donax) }\end{array}$ & - & - & - & 100 & [104] \\
\hline & RBC(pilot Scale) & Acetic Acid & 0.15 & 40 & 0.11 & 98 & [69] \\
\hline & FBR(Full Scale) & Ethanol & 254 & - & 4.35 & - & [33] \\
\hline & Fixed Film(Full Scale) & Acetic Acid & 800 & $12-22$ & $2.5-3.5$ & 70 & [83] \\
\hline & In-Situ Treatment & Sucrose & 50 & 13.5 & 0.07 & 10 & {$[42]$} \\
\hline & In-Situ Treatment & Cellulose & 60 & 13 & 0.008 & 20 & [43] \\
\hline \multirow[t]{7}{*}{ Autotrophic } & Fixed Bed(Full Scale) & Sulphur & - & 18.1 & - & 94 & {$[31]$} \\
\hline & SLAD Process (Pilot Scale) & Sulphur & - & $10-94$ & - & $>95$ & {$[102]$} \\
\hline & SLAD Process (Pilot Scale) & Sulphur & - & 30 & - & $95-100$ & [103] \\
\hline & Upflow Biofilter (Lab Scale) & Sulphur & - & $10-100$ & - & 95 & {$[24]$} \\
\hline & Packed-bed bioreactor & Sulphur & - & $18 \mathrm{mmol} / \mathrm{L}$ & - & 95.9 & [99] \\
\hline & Fixed Bed (Full Scale) & Hydrogen & 35 & 18.1 & 0.6 & 95 & {$[30]$} \\
\hline & Fixed Bed (Pilot Scale) & Hydrogen & 50 & 18 & 0.85 & 97 & [89] \\
\hline
\end{tabular}

${ }^{a}$ Rotating Biological Contactor(RBC); Intensified Biofilm-Electrode Reactor (IBER); Membrane Bioreactor(MBR);Sulphur/limestone autotrophic denitrification (SLAD); Fluidized Bed Reactor(FBR).

${ }^{\mathrm{b}}$ Nitrate Removal Rate.

ii. The main sources of carbon source for heterotrophic denitrification are methanol, ethanol and acetic acid. Methanol was found to be cheapest but with possible toxic effects. The use of ethanol is becoming more popular. However acetic acid was found to be more effective in removal of nitrate with low intermediate nitrite in the effluent.

iii. Heterotrophic denitrified water requires post treatment to eliminate residual carbon source from the drinking water and to remove undesirable organic matter which would sustain the regrowth of micro-organisms in the distribution system.

iv. Autotrophic denitrification does not require organic carbon, some inorganic compounds such as hydrogen gas and sulphur for electron donor and bicarbonate or carbon dioxide in the water as a carbon source.

v. Autotrophic denitrified water also needs post treatment for degasification and for removal of biomass. vi. Autotrophic growth rate is lower than heterotrophic; therefore, the sludge production is low but the efficiency of nitrate removal also lower.

vii. Autotrophic denitrification control is more complex than hetrotrophic, because of the three phase (gas, liquid and solid) process.

\section{Competing interests}

All authors declare that they have no competing interests.

\section{Authors' contributions}

MAZ has searched, completed and finalized the draft of the manuscript. AMB supervised the study and performed the first draft. DJE was advisor of the study. All authors read and approved the final manuscript.

\section{Acknowledgements}

The corresponding author would like to thank Dr. Edris Bazrafshan for his helpful comments. It is also worth to say that there is no direct relation or financial support by any commercial companies mentioned in this paper. 


\section{Author details}

'Department of Environmental Health Engineering, School of Public Health, Shahid Beheshti University of Medical Sciences, Tehran, Iran. ${ }^{2}$ School of Civil Engineering, University of Newcastle, Newcastle upon Tyne, NE1 7RU, UK. ${ }^{3}$ Department of Environmental Health Engineering, Health Sciences Research Center and Faculty of Health, Mazandaran University of Medical Sciences, Sari, Iran.

Received: 6 April 2013 Accepted: 25 September 2013

Published: 19 December 2013

\section{References}

1. Panno SV, Kelly WR, Hackley KC, Hwang H-H, Martinsek AT: Sources and fate of nitrate in the Illinois River Basin, Illinois. J Hydrol 2008, 359:174-188.

2. Mirvish SS: Formation of N-nitroso compounds: chemistry, kinetics, and in vivo occurrence. Toxicol Appl Pharmacol 1975, 31:325-351.

3. Nabil Alaa El-Din M, Madany IM, Al-Tayaran A, Hakeem Al-Jubair A, Gomaa A: Trends in water quality of some wells in Saudi Arabia, 1984-1989. Sci Total Environ 1994, 143:173-181.

4. Shrimali M, Singh KP: New methods of nitrate removal from water. Environ Pollut 2001, 112:351-359.

5. Neal C, Jarvie HP, Neal M, Hill L, Wickham H: Nitrate concentrations in river waters of the upper Thames and its tributaries. Sci Total Environ 2006, 365:15-32.

6. Power JF, Schepers JS: Nitrate contamination of groundwater in North America. Agri Ecosyst Environ 1989, 26:165-187.

7. Rasiah $V$, Armour JD, Nelson PN: Nitrate in shallow fluctuating groundwater under sugarcane: Quantifying the lateral export quantities to surface waters. Agri Ecosyst Environ 2012. In press.

8. Sadeq M, Moe CL, Attarassi B, Cherkaoui I, ElAouad R, Idrissi L: Drinking water nitrate and prevalence of methemoglobinemia among infants and children aged 1-7 years in Moroccan areas. Int J Hyg Environ Health 2008, 211:546-554.

9. Xie Y-X, Xiong Z-Q, Xing G-X, Sun G-Q, Zhu Z-L: Assessment of nitrogen pollutant sources in surface waters of Taihu lake region. Pedosphere 2007, 17:200-208.

10. Jalali M: Nitrate pollution of groundwater in Toyserkan, western Iran. Environ Earth Sci 2011, 62:907-913.

11. Della Rocca C, Belgiorno V, Meriç S: Overview of in-situ applicable nitrate removal processes. Desalination 2007, 204:46-62.

12. Choi J-H, Maruthamuthu S, Lee H-G, Ha T-H, Bae J-H: Nitrate removal by electro-bioremediation technology in Korean soil. J Hazard Mater 2009, 168:1208-1216.

13. Hell F, Lahnsteiner J, Frischherz $H$, Baumgartner G: Experience with fullscale electrodialysis for nitrate and hardness removal. Desalination 1998, 117:173-180.

14. Song H, Zhou Y, Li A, Mueller S: Selective removal of nitrate from water by a macroporous strong basic anion exchange resin. Desalination 2012, 296:53-60.

15. van der Hoek JP, Klapwijk A: Nitrate removal from ground water. Water Res 1987, 21:989-997.

16. J V, P D, M V J J , W V and KERSTERS: Isolation and identification of autotrophic and heterptrophic bacteria from an authohydrogenothrophic pilot-plant for denitrification of drinking water. Syst Appl Microbiol 1993, 16:471-482

17. Yang T, Doudrick K, Westerhoff $P$ : Photocatalytic reduction of nitrate using titanium dioxide for regeneration of ion exchange brine. Water Res 2013, 47:1299-1307.

18. Zhang $Y$, Angelidaki I: A new method for in situ nitrate removal from groundwater using submerged microbial desalination-denitrification cell (SMDDC). Water Res 2013, 47:1827-1836.

19. Kim Y-J, Kim J-H, Choi J-H: Selective removal of nitrate ions by controlling the applied current in membrane capacitive deionization (MCDI). J Memb Sci 2013, 429:52-57.

20. Barbosa DP, Tchiéta P, Rangel MC, Epron F: The use of a cation exchange resin for palladium-tin and palladium-indium catalysts for nitrate removal in water. J Mol Catalys 2013, 366:294-302.

21. Hale SE, Alling V, Martinsen V, Mulder J, Breedveld GD, Cornelissen G: The sorption and desorption of phosphate-P, ammonium- $\mathrm{N}$ and nitrate- $\mathrm{N}$ in cacao shell and corn cob biochars. Chemosphere 2013, 9:1612-1619.
22. van der Hoek JP, van der Ven PJM, Klapwijk A: Combined ion exchange/ biological denitrification for nitrate removal from ground water under different process conditions. Water Res 1988, 22:679-684.

23. Ergas SJ, Rheinheimer DE: Drinking water denitrification using a membrane bioreactor. Water Res 2004, 38:3225-3232.

24. Zhou W, Sun Y, Wu B, Zhang Y, Huang M, Miyanaga T, Zhang Z: Autotrophic denitrification for nitrate and nitrite removal using sulfurlimestone. J Environ Sci 2011, 23:1761-1769.

25. Zhao Y, Feng C, Wang Q, Yang Y, Zhang Z, Sugiura N: Nitrate removal from groundwater by cooperating heterotrophic with autotrophic denitrification in a biofilm-electrode reactor. J Hazard Mater 2011, 192:1033-1039.

26. Koenig A, Zhang T, Liu LH, Fang HH: Microbial community and biochemistry process in autosulfurotrophic denitrifying biofilm. Chemosphere 2005, 58:1041-1047.

27. $\mathrm{BE} J$, Crowe PB: Biological processes in drinking water treatment. J Am Wat Wks Assoc 1988, M(9):82-93.

28. Lichtwardt M, Hart B: Biological Nitrate Removal Pretreatment for a Drinking Water Application. In Book Biological Nitrate Removal Pretreatment for a Drinking Water Application. Denver: Water Research Foundation; 2010.

29. Richarf $Y$, Thebult P: Biological removal of nitrates- report on 7 years of operation and progress. Water Supp/ 1992, 10:151.

30. Gross H, Schnoor G, Treuter K: Nitrate removal from groundwater by autotrophic microorganisms. Water Supp/ 1986, 4:11-21.

31. Kruithof JC, van Bennekom CA, Dierx HA, Hijnen WAM, van Paassen JAM, Schooners JC: Nitrate removal from groundwater by sulphur/limestone filtration. Water Supp/ 1988, 6:207-217.

32. Rogalla F, Ravarini P, De Larminat G, Couttelle J: Large-scale biological nitrate and ammonia removal. Wat Environ J 1990, 4:311-401.

33. Boehler $E$, Haldenwang L, Schwabe $G$ : Results and experience with the NEBIO tube reactor process in the water treatment plant coswig near Dresden. Water Sci Technol 1994, 29:497-508.

34. van Veldhuizen HM, van Loosdrecht MCM, Heijnen JJ: Modelling biological phosphorus and nitrogen removal in a full scale activated sludge process. Water Res 1999, 33:3459-3468.

35. Show K-Y, Lee D-J, Pan X: Simultaneous biological removal of nitrogensulfur-carbon: Recent advances and challenges. Biotechnol Adv 2013 31:409-420.

36. Richard $Y$ : Operating experiences of full-scale biological and ionexchange denitrification plants in France. J Inst Water Environ Manage 1989, 3:154-167.

37. lessens J, Germonpre R, Verstraete W: Comparative study of processes for the biological denitrification of drinking water. J Mededelingen van de Faculteit Landbouwwetenschappen, Rijksuniversiteit Gent 1990, 54:1415-1435.

38. Hamlin HJ, Michaels JT, Beaulaton CM, Graham WF, Dutt W, Steinbach P, Losordo TM, Schrader KK, Main KL: Comparing denitrification rates and carbon sources in commercial scale up flow denitrification biological filters in aquaculture. Aquacult Engr 2008, 38:79-92.

39. Fernández-Nava Y, Marañón E, Soons J, Castrillón L: Denitrification of high nitrate concentration wastewater using alternative carbon sources. J Hazard Mater 2010, 173:682-688.

40. Xu Y, Qiu TL, Han ML, Li J, Wang XM: Heterotrophic denitrification of nitrate-contaminated water using different solid carbon sources. Procedia Environ Sci 2011, 10(Part A):72-77

41. Shen Z, Zhou Y, Hu J, Wang J: Denitrification performance and microbial diversity in a packed-bed bioreactor using biodegradable polymer as carbon source and biofilm support. J Hazard Mater 2013, 15:431-438.

42. Mercado A, Libhaber M, Soare MIM: In situ biological groundwater denitrification: concepts and preliminary field tests. Water Sci Technol 1988, 20:97-209.

43. Boussaid F, Martin G, Morvan J, Collin JJ, Landreau A, Talbob H: Denitrification in situ of groundwaters with solid carbon matter. Environ Technol Lett 1988, 9:803-816.

44. Akunna JC, Bizeau C, Moletta R: Nitrate and nitrite reductions with anaerobic sludge using various carbon sources: Glucose, glycerol, acetic acid, lactic acid and methanol. Water Res 1993, 27:1303-1312.

45. Blaszczyk M: Effect of medium composition on the denitrification of nitrate by paracoccus denitrificans. Appl Environ Microbiol 1993, 59:3951-3953.

46. Ayyasamy PM, Shanthi K, Lakshmanaperumalsamy P, Lee S-J, Choi N-C, Kim D-J: Two-stage removal of nitrate from groundwater using biological and chemical treatments. J Biosci Bioengr 2007, 104:129-134. 
47. Hall T, Zabel T: Bilogical denitrification of potable water. In Book Bilogical denitrification of potable water. Medmenham: Water Research Center; 1984.

48. Ghararah ZHA: Biological denitrification of high nitrate water: Influence of type of carbon source and nitrate loading. J Environ Sci Health Part A 1996, 31:1651-1668.

49. Mohseni-Bandpi A, Elliott DJ, Momeny-Mazdeh A: Denitrification of groundwater using acetic acid as a carbon source. Water Sci Technol 1999, 40:53-59.

50. Magram SF: Drinking water denitrification in a packed Bed anoxic reactor: effect of carbon source and reactor depth. J App/ Sci 2010, 10:558-563.

51. Green M, Shnitzer M, Tarre S, Bogdan B, Shelef G, Sorden CJ: Fluidized bed reactor operation for groundwater denitrification. Water Sci Technol 1994, 29:509-515.

52. Roennefhart KW: Nitrate elimination with heterotrophic aquatic microorganisms' in fixed bed reactors with buoyant carriers. Aq. Aqua 1986, 5:283-285.

53. UKDOE: Effects of Nitrate Removal on Water Quality in Distribution. In Book Effects of Nitrate Removal on Water Quality in Distribution. Birmingham: Consulants in Environmental Sciences; 1987.

54. Her JJ, Huang JS: Influences of carbon source and C/N ratio on nitrate/ nitrite denitrification and carbon breakthrough. Biores Technol 1995, 54:45-51.

55. Gabaldón C, Izquierdo M, Martínez-Soria V, Marzal P, Penya-roja JM, Javier Alvarez-Hornos F: Biological nitrate removal from wastewater of a metalfinishing industry. J Hazard Mater 2007, 148:485-490.

56. Moore SF, Schroeder ED: An investigation of the effects of residence time on anaerobic bacterial denitrification. Water Res 1970, 4:685-694.

57. Moore SF, Schroeder ED: The effect of nitrate feed rate on denitrification. Water Res 1971, 5:445-452.

58. Stouthamer A: Metabolic pathways inParacoccus denitrificans and closely related bacteria in relation to the phylogeny of prokaryotes. Antonie Van Leeuwenhoek 1992, 61:1-33.

59. Jeris JS, Beer C, Mueller JA: High rate biological denitrification using a granular fluidized. J (Water Poll Cont Fed) 1974, 46:2118-2128.

60. McCarty PL, Beck L, St. Amant P: Biological denitrification of wastewaters by addition of organic materials. California, USA: Federal Water Pollution Control; 1969

61. Liessens J, Germonpre R, Beernaert S, Verstraete W: Removing Nitrate with a methylotrophic fluidized Bed: technology and operating performance. J Am Water Works Assoc 1993, 84:144-154.

62. METCALF \& EDDY I: Advanced Wastewater Treatment. Removal of Nitrogen by Biological Nitrification J Denitrification. Wastewater Engineering: Treatment, Disposal and Reuse. New York: McGraw-Hill, Inc; 1991

63. Cherchi C, Onnis-Hayden A, El-Shawabkeh I, Gu AZ: Implication of using different carbon sources for denitrification in wastewater treatments. Water Environ Res 2009, 81:788-799.

64. Jensen VB, Darby JL: Drinking Water Treatment for Nitrate. In Book Drinking Water Treatment for Nitrate vol. Technical Report 6. California: University of California, Davis; 2012.

65. Novogrodsky A, Ravid A, Rubin AL, Stenzel KL: Hydroxyl radical scavengers inhibit lymphocyte mitogenesis. Proc Natl Acad Sci USA 1982, 79:1171-1174.

66. Im H, Oh E, Mun J, Khim JY, Lee E, Kang HS, Kim E, Kim H, Won NH, Kim YH, et al: Evaluation of toxicological monitoring markers using proteomic analysis in rats exposed to formaldehyde. J Proteome Res 2006, 5:1354-1366.

67. Mohseni-Bandpi A, Elliott DJ: Methanol as a carbon source for the denitrification of groundwater using rotating biological contactor. In 68th Annual conference. USA: Water Environment Federation; 1995:487-494.

68. Mohseni-Bandpi A, Elliott DJ: Nitrate removal from groundwater using an anoxicaerobic rotating biological contactor. Water Sci Technol 1996, 34:323-330

69. Mohseni-Bandpi A, Elliott DJ: Groundwater denitrification with alternative carbon sourcese. Water Sci Technol 1998, 38:237-243.

70. Chang NB, Wanielista M, Daranpob A: Fiter media for nutrient removal in natural systems and built environments: I-design and application challenges. Environ Engr Sci 2010, 27:707-720.

71. Croll BT, Hall T, Zabel TR: Bilogical Fluidised Bed Denitrification for Potable Water. In Book bilogical Fluidised Bed Denitrification for Potable Water. Birmingham University: international Conference; 1985.
72. Atta NM: Removal of nitrate from waters and effluents using attached microbial biomass. United Kingdom: Leeds Univ; 1989.

73. Gauntlett RB: Denitrification kinetics in a fluidised bed using methanol as the carbon source. Biotechnol Lett 1979, 1:391-396.

74. Hiscock KM, Lloyd JW, Lerner DN: Review of natural and artificial denitrification of groundwater. Water Res 1991, 25:1099-1111.

75. Hamersley MR, Howes BL: Control of denitrification in a septage-treating artificial wetland: the dual role of particulate organic carbon. Water Res 2002, 36:4415-4427.

76. Richard LS, Marnie LC, Myron HB: Autotrophic, hydrogen-oxidizing, denitrifying bacteria in groundwater, potential agents for bioremediation of nitrate contamination. Appl Environ Microbiol 1994, 60:1949-1955.

77. Mohseni-Bandpi A, Elliott DJ: Nitrate removal from groundwater using an anoxicaerobic rotating biological contactor. In Book Nitrate removal from groundwater using an anoxicaerobic rotating biological contactor. Miami Beach, Florida: Water Environment Federation; 1995.

78. Pohanish RP: Sittig's Handbook of Toxic and Hazardous Chemicals and Carcinogens. 6th edition. USA: Elsevier Inc; 2011.

79. Mekonen A, Kumar $\mathrm{P}$, Kumar $\mathrm{A}$ : Use of sequencing batch reactor for biological denitrification of high nitrate-containing water. J Environ Engr 2001, 127:273-278

80. Dahab MF, Lee YW: Nitrate removal from water supplies using biological denitrification. J (Water Poll Cont Fed) 1988, 60:1670-1674.

81. Dahab MF, Kalagiri J: Nitrate removal from water using cyclically operated fixedfilm bio-denitrification reactors. Water Sci Technol 1996, 34:331-338.

82. Rchna, Sharma SK, Chander Sobti R: Nitrate removal from ground water: a review. E-J Chem 2012, 9:1667-1675.

83. Bockle R, Rohmann U, Wertz A: A process for restoring nitrate contaminated groundwater by means of heterotrophic denitrification in an activated carbon filter and anaerobic post-treatment underground. Aqua 1986, 5:286-287.

84. Chang CC, Tseng SK, Huang HK: Hydrogenotrophic denitrification with immobilized Alcaligenes eutrophus for drinking water treatment. Biores Technol 1999, 69:53-58.

85. Rezania B, Cicek N, Oleszkiewicz JA: Kinetics of hydrogen-dependent denitrification under varying $\mathrm{pH}$ and temperature conditions. Biotech Bioengr 2005, 92:900-906.

86. Vasiliadou IA, Siozios S, Papadas IT, Bourtzis K, Pavlou S, Vayenas DV: Kinetics of pure cultures of hydrogen-oxidizing denitrifying bacteria and modeling of the interactions among them in mixed cultures. Biotech Bioengr 2006, 95:513-525.

87. Kurt M, Dunn IJ, Bourne JR: Biological denitrification of drinking water using autotrophic organisms with $\mathrm{H} 2$ in a fluidized-bed biofilm reactor. Biotech Bioengr 1987, 29:493-501.

88. Grommen $\mathrm{R}$, Verhaege $M$, Verstraete $W$ : Removal of nitrate in aquaria by means of electrochemically generated hydrogen gas as electron donor for biological denitrification. Aquacult Engr 2006, 34:33-39.

89. Rutten $\mathrm{P}$, Schnoor G: Five years' experience of nitrate removal from drinking water. Water supp/ 1992, 10:183-190.

90. Batchelor B, Lawrence AW: Autotrophic denitrification using elemental sulfur. J Water Poll Cont Fed 1978, 50:1075-1084

91. Hoek JVD, Kappelhof J, Hijnen W: Biological Nitrate removal from ground water by sulfur/limestone denitrification. Chem Inform 1992, 23:318.

92. Kimura K, Nakamura M, Watanabe $Y$ : Nitrate removal by a combination of elemental sulfur-based denitrification and membrane filtration. Water Res 2002, 36:1758-1766.

93. Wang H, Qu J: Combined bioelectrochemical and sulfur autotrophic denitrification for drinking water treatment. Water Res 2003, 37:3767-3775.

94. Soares MIM: Denitrification of groundwater with elemental sulfur. Water Res 2002, 36:1392-1395.

95. Darbi A, Viraraghavan T, Butler R, Corkal D: Column studies on nitrate removal from potable water. Water Air Soil Poll 2003, 150:235-254.

96. Moon HS, Shin do Y, Nam K, Kim JY: A long-term performance test on an autotrophic denitrification column for application as a permeable reactive barrier. Chemosphere 2008, 73:723-728.

97. Brettar I, Labrenz M, Flavier S, Botel J, Kuosa H, Christen R, Hofle MG: Identification of a Thiomicrospira denitrificans-like epsilonproteobacterium as a catalyst for autotrophic denitrification in the central Baltic Sea. Appl Environ Microbiol 2006, 72:1364-1372.

98. Sengupta S, Ergas SJ: Autotrophic Biological Denitrification with Elemental Sulfur or Hydrogen for Complete Removal of Nitrate-Nitrogen 
from a Septic System Wastewater. In Book Autotrophic Biological Denitrification with Elemental Sulfur or Hydrogen for Complete Removal of Nitrate-Nitrogen from a Septic System Wastewater. New Hampshire: The NOAA/UNH Cooperative Institute for Coastal and Estuarine Environmental Technology (CICEET); 2006.

99. Sierra-Alvarez R, Beristain-Cardoso R, Salazar M, Gomez J, Razo-Flores E, Field JA: Chemolithotrophic denitrification with elemental sulfur for groundwater treatment. Water Res 2007, 41:1253-1262.

100. Darbi A, Viraraghavan T, Butler R, Corkal D: Batch studies on nitrate removal from potable water. Water SA 2002, 28:319-322.

101. Schippers CJ, Kruithof C: Removal of nitrate by slow sulfur/limestone filtration. Aqua 1987, 5:274-280.

102. Darbil D, Viraraghavan T, Butler R, Corkal D: Batch studies on nitrate removal from potable water. Water SA 2002, 28:319-322.

103. Flere JM, Zhang TC: Remediation of nitrate-contaminated surface water using sulfur and limestone autotrophic denitrification processes. Water Sci Technol 1998, 38:15.

104. Ovez B, Ozgen S, Yuksel M: Biological denitrification in drinking water using Glycyrrhiza glabra and Arunda donax as the carbon source. Proc Biochem 2006, 41:1539-1544.

doi:10.1186/2052-336X-11-35

Cite this article as: Mohseni-Bandpi et al:: Biological nitrate removal processes from drinking water supply-a review. Journal of Environmental Health Sciences \& Engineering 2013 11:35.

\section{Submit your next manuscript to BioMed Central and take full advantage of:}

- Convenient online submission

- Thorough peer review

- No space constraints or color figure charges

- Immediate publication on acceptance

- Inclusion in PubMed, CAS, Scopus and Google Scholar

- Research which is freely available for redistribution 